\title{
Особливості хірургічного лікування дивертикулів стравоходу великих розмірів
}

\section{В. В. Яцків ${ }^{1,2}$, І. Ю. Полянськийі ${ }^{1}$ С. Е. Фрімет ${ }^{2}$, В. П. Сливка², Ю. Д. Лук'янчук², С. М. Мереуца ${ }^{1}$ Буковинський державний медичний університет, м. Чернівці, \\ 2Чернівецька обласна клінічна лікарня \\ Peculiarities of surgical treatment of esophageal diverticula of large dimensions}

\author{
V. V. Yatskyv ${ }^{1,2}$, I. Yu. Polyansky' , S. E. Frimet ${ }^{2}$, V. P. Slyvka², Yu. D. Lukyanchuk ${ }^{2}$, S. M. Mereuca ${ }^{2}$ \\ ${ }^{1}$ Bukovyna State Medical University, Chernivtsi, \\ ${ }^{2}$ Chernivtsi Regional Clinical Hospital
}

\section{Реферат}

Мета. Покращити результати хірургічного лікування дивертикулів стравоходу (ДС) шляхом удосконалення методик оперативних втручань 3 метою попередження виникнення післяопераційних ускладнень.

Матеріали і методи. Узагальнено досвід лікування 58 хворих з ДС різної локалізації. У 13,8\% хворих були ДС розмірами понад 5 см. Дисфагію як основний клінічний прояв ДС спостерігали у 32 (55,2\%) хворих, безсимптомний перебіг захворювання - у 3(5,2\%), ускладнений - у 39 (67,2\%). У всіх хворих з ДС великих розмірів діагностовано дивертикуліт. Виражений перифокальний фіброз, формування залишкових порожнин ДС виявлено у 5 (8,6\%) хворих. Вираженість фіброзу відповідала тривалості захворювання від 4 до 10 років.

Результати. Дивертикулектомію відкритим способом виконали 58 хворим, симультанні операції 3 приводу ахалазії стравоходу - 3. Субопераційно використовували ендоскопічну підтримку. Фенестрацію фіброзних залишкових порожнин виконували з застосуванням електрозварювальних технологій. Післяопераційні ускладнення виникли у 2 (3,4\%) хворих. Жоден паціент не помер. ДС великих розмірів мають широке устя неправильної форми, у зв'язку з чим у 4 хворих використано клиноподібний механічний шов у поперечному напрямку. Контрольні дослідження проведені в строки до 1 року просвіт стравоходу повністю збережений, цілісність не порушена.

Висновки. Хірургічне лікування ДС великих розмірів обгрунтоване. Застосовувати сучасні методи діагностики потрібно як на доопераційному етапі, так і субопераційно. У разі формування ДС великих розмірів із широким устям, фіброзних залишкових порожнин доцільно застосовувати клиноподібний шов основи ДС за допомогою ендостеплерів, фенестрацію 3 використанням електрозварювальних технологій для зменшення ризику виникнення післяопераційних ускладнень.

ключові слова: дивертикул стравоходу; фенестрація залишкової порожнини; електрозварювання тканин; клиноподібний шов стравоходу.

\section{Abstract}

Objective. To improve the results of surgical treatment of esophageal diverticulas (ED), using the improved procedures of operative interventions for prevention of the morbidity occurrence.

Materials and methods. Experience of treatment of 58 patients, having ED of various localization, is adduced. In $13.8 \%$ patients the ED were over $5 \mathrm{~cm}$ in size. Dysphagia as a principal clinical sign and was observed in $32(55.2 \%)$ patients, the disease course was free of symptoms in 3(5.2\%), and a complicated one - in 39 (67.2\%). In all the patients with ED, owing large size, a diverticulitis was diagnosed. Prominent perifocal fibrosis, formation of residual cavities in ED were revealed in 5 (8.6\%) patients. The fibrosis severity was correlated with the disease duration from 4 to 10 yrs.

Results. The open operative access was performed in 58 patients, and simultant operations for achalasia - in 3. Endoscopic support was applied suboperatively. Fenestration of fibrotic residual cavities was applied, using the electric welding technologies. Postoperative complications have occurred in $2(3.4 \%)$ patients. There was no lethality. ED of large size have wide mouth of incorrect form, that's why in 4 patients a wedge-like mechanical suture in a transverse direction was applied. Follow-up investigations were conducted in terms up to $1 \mathrm{yr}$, the esophageal lumen was completely preserved and was free of defects.

Conclusion. Surgical treatment of ED is a well established way of their management. Modern methods of diagnosis must be applied preoperatively and suboperatively. For ED of large size, owing wide mouth, fibrotic residual cavities it is expedient to use a wedge-like suture at the base of ED with the help of endostaplers, and fenestration, using electric welding technologies for reduction of the morbidity occurrence risk.

Keywords: esophageal diverticula; fenestration of residual cavity; electric welding of tissues; a wedge-like esophageal suture.

Дивертикули стравоходу (ДС) становлять 0,5 - 7,7\% всіх захворювань стравоходу [1], а частка наддіафрагмальних ДС у структурі даної патології сягає 10\% [2]. У доступній літературі статистичних даних стосовно частоти ДС великих розмірів нами не знайдено, так само як і загальноприйнятого визначення «дивертикул великих розмірів».
Зокрема, такими вважають ДС розмірами більше 2 см [3], більше 5 см [4], білыше 6 см [5]. Є повідомлення про хірургічне лікування епіфренальних ДС розмірами більше 10 см [6]. Окремі автори $[2,6]$ вказують на такі особливості ДС великих розмірів, як формування широкого устя, ступінь запальних, дистрофічних змін стінок дивертикула, 
що потребує додаткової підготовки хворих, модифікації техніки оперативних втручань з метою зменшення частоти виникнення післяопераційних ускладнень.

Стандартів хірургічного лікування ДС, як і показань до виконання операцій не встановлено. На думку окремих авторів $[4,7]$, рішення про використання хірургічних методів лікування ДС є спірним. За безсимптомними ДС будьяких розмірів слід спостерігати з рекомендаціями щодо лікування та харчування. Водночас у разі виявлення дивертикулів розмірами 2 і більше сантиметрів показано оперативне втручання, якщо наявні тривала затримка барієвої суміші або дивертикуліт [3].

Класичні оперативні втручання з приводу ДС запропоновані ще в XIX столітті, а саме висічення (Kluge,1850) та інвагінація (Girard, 1896) дивертикула, які використовують і нині. Операцією вибору вважають дивертикулектомію з укріпленням стінки стравоходу клаптем плеври або діафрагми (Б. В. Петровський - Е. Н. Ванцян, 1964) $[1,8]$. Сучасні методики (2010 - 2018 рр.) грунтуються на широкому використанні відеохірургічних, ендоскопічних втручань [3 - 5]. За даними окремих авторів, частота неспроможності шва стравоходу після вказаних операцій сягає 33\% [2].

Значний інтерес до оперативних втручань 3 приводу ДС великих розмірів пов'язаний з прогнозованими технічними труднощами їх мобілізації, вибором індивідуальних методик закриття дефекту стравоходу, рішення щодо яких нерідко доводиться приймати безпосередньо під час операції.

Отже, питання хірургічного лікування ДС, зокрема ДС великих розмірів, є актуальним. Потрібні індивідуальний підхід до визначення показань до оперативних втручань, тривалості передопераційної підготовки, удосконалення окремих етапів оперативних втручань.

Мета дослідження: покращити результати хірургічного лікування ДС шляхом удосконалення методик оперативних втручань з метою попередження виникнення післяопераційних ускладнень.

\section{Матеріали і методи дослідження}

У Чернівецькій обласній клінічній лікарні за період 3 2010 по 2017 р. проведено лікування 58 хворим з ДС різної локалізації. Чоловіків було 48, жінок - 10 у віці від 35 до 68 років. Глотково-стравохідні ДС (Ценкера) спостерігали у 7 (12,1\%) хворих, середньої третини стравоходу у 12 (20,7\%), нижньої третини - у 38 (65,5\%). ДС великих розмірів (більше 5 см у діаметрі по зовнішньому контуру) діагностовано у 8 (13,8\%) хворих. У 2 хворих епіфренальні ДС були поєднані з ахалазією стравоходу, у 3 - 3 виразковою хворобою шлунка.

Основним клінічним проявом ДС у 32 (55,2\%) пацієнтів була дисфагія, причому у хворих з ДС великих розмірів - 3 - 4 ступеня за S. Bown (1987), у 28 (48,3\%) - відрижка з регургітацією їжі, вираженість якої відповідала розмірам дивертикулів. Значно частіше на відрижку скаржились пацієнти з дивертикулами Ценкера. Менш вираженими симптомами були біль у грудній порожнині - у 22 (37,9\%) хворих, стійкий кашель внаслідок попадання вмісту дивертикулів у бронхіальне дерево - у 21 (36,2\%) хворого. ДС у 3
(5,2\%) хворих, виявлені під час ендоскопічного обстеження $з$ приводу виразкової хвороби шлунка, мали безсимптомний перебіг. Стандартом обстеження вважаємо езофагогастрографію, комп'ютерну томографію (КТ) органів грудної порожнини (ОГП), фіброезофагогастроскопію. У всіх 8 (13,8\%) пацієнтів з ДС великих розмірів діагностовано дивертикуліт, у 2 - 3 виразкуванням, вони потребували додаткової передопераційної підготовки. Під час ендоскопічного обстеження звертали увагу на розмір і ширину устя дивертикула, які у 6 (10,3\%) хворих перевищували 5 см. Під час КТ ОГП проводили диференціальну діагностику з іншими захворюваннями стравоходу, середостіння, вивчали ступінь перифокальних фіброзних змін навколишніх тканин, особливо у хворих з ДС великих розмірів. У більшості пацієнтів вираженість фіброзу відповідала тривалості захворювання, яка, за нашими даними, становила від 4 до 10 років. Виражений перифокальний фіброз виявлено у 5 (8,6\%) хворих, що підтверджено субопераційно.

Усім пацієнтам виконані оперативні втручання відкритими методами, у пацієнтів з ДС великих розмірів - з ендоскопічною підтримкою. За наявності виражених перифокальних фіброзних змін тканин застосовували електрозварювальні технології за допомогою апарата ЕК-300М1.

\section{Результати}

Оперованим 58 хворих з ДС виконано 60 оперативних втручань: 58 дивертикулектомій відкритим способом; 2 $(3,4 \%)$ хворим операції виконано повторно у зв'язку з виникненням ускладнень ( 1 - торакоскопічну фенестрацію залишкової порожнини дивертикула через ії нагноєння, 1 - дренування плевральної порожнини з приводу емпієми плеври). У 3 хворих виконані симультанні операції з приводу ахалазії стравоходу. Жоден пацієнт не помер.

Хірургічні доступи при ДС великих розмірів були ідентичними стандартним, залежали від локалізації дивертикула: глотково-стравохідний (1), біфуркаційний (1), епіфренальний (6), водночас враховували наявність вираженого перифокального фіброзу, інфільтративних змін, що ускладнювало мобілізацію ДС. За таких обставин для мобілізації ДС використовували технології зварювання тканин, що зменшувало глибину коагуляційних уражень, об'єм крововтрати і було важливим в умовах складності візуалізації змінених стінок органів і судин. Враховуючи сегментарний тип кровопостачання частково середньої та нижньої третин стравоходу, забезпечували, наскільки можливо, щадне виділення стінок дивертикула.

Однією з особливостей операцій з приводу ДС великих розмірів $€$ наявність у окремих хворих залишкової порожнини після резекції дивертикула, представленої фіброзними капсулами, запально зміненими навколишніми тканинами. На початкових етапах накопичення досвіду нами було недооцінено вказані особливості у зв'язку з впевненістю в достатній ефективності подвійного дренування плевральної порожнини та середостіння. Наводимо клінічне спостереження, яке змусило нас переглянути тактику.

Хворий К., 52 р., оперований у 2015р. 3 приводу ДС великих розмірів, розташованого в нижній третині стравоходу. Об'єм операції: торакотомія зліва, резекція дивертику- 
ла, укріплення стінки стравоходу навколишніми тканинами, дренування плевральної порожнини та середостіння. У зв'язку з припиненням виділень після рентгенологічного контролю та ультразвукового дослідження дренажі видалені на 4-й день після операції. На 8-й день стан хворого різко погіршився, діагностовано нагноєння залишкової порожнини з проривом у плевральну порожнину, у зв'язку з чим виконано торакоскопічну фенестрацію та дренування залишкової порожнини. Хворий одужав.

Після аналізу ситуації стало очевидним, що зовнішній контур залишкової порожнини після резекції ДС великих розмірів закривається досить швидко, а ексудація продовжується з можливим їі нагноєнням, оскільки операції на стравоході є умовно інфікованими. У зв'язку з наведеним ми виконуємо додаткову фенестрацію залишкової порожнини, максимально можливо видаляємо фіброзні тканини за допомогою електрозварювання в режимі «перекриття» для збільшення податливості стінок порожнини. Такий спосіб був застосований у 4 хворих. Ускладнень не спостерігали. Всі 4 хворих одужали.

Дивертикулектомію виконували під контролем ендоскопа, що уможливлювало підсвічування тканин, роздування стравоходу для виділення окремих кишень дивертикула, проведення водяної проби на герметичність. Ушивання основи дивертикулів великих розмірів виконували зшиваючим апаратом у поперечному напрямку з укріпленням клаптем плеври, у разі можливості - сусідніми тканинами. ДС, основа яких перевищувала 6 см, займала дві третини окружності стінки, прошивали клиноподібно в поперечному напрямку без звуження просвіту стравоходу (ширина бранш зшиваючого апарата - 6 см). Слабке місце шва - кут через можливе накладання скобок, у зв'язку з чим додатково прошивали стінку стравоходу окремими ручними швами з наступним виконанням водяної проби на герметичність (роздування стравоходу через ендоскоп із зануренням зони шва під шар фізіологічного розчину). Вказана методика використана у 4 хворих. Контрольні ендоскопічні та рентгенологічні дослідження через 6 міс - 1 рік показали, що просвіт стравоходу повністю збережений, цілісність не порушена.

\section{Обговорення}

Причини виникнення глотково-стравохідних, біфуркаційних ДС достатньо вивчені; дивертикули нижніх відділів стравоходу, з практичної точки зору, переважно пульсійні, формуються внаслідок слабості стінки, проте незрозуміло, чому ця слабість виникає [9]. Чимало дослідників наводять дані про поєднання слабості м'язових скорочень стравоходу з ахалазією [6, 7]. У нашій практиці був приклад оперативного лікування хворого Р., 46 р., з ахалазією стравоходу IV ступеня без будь-яких ознак розвитку дивертикула. Зі слів пацієнта, для проходження їжі в шлунок йому доводилось випивати щодня до 8 л рідини. Тривалість захворювання - майже 10 років. Об'єм оперативного втручання - формування езофагогастроанастомоза. Пацієнт виписаний після відновлення прохідності стравоходу. Помер через 6 міс через прогресування основного захворювання - цирозу печінки змішаної етіології.

Хірургічне лікування ДС великих розмірів має свої особливості через переважно ускладнений перебіг захворю- вання, формування, в окремих спостереженнях, фіброзно змінених залишкових порожнин. Ускладнений перебіг ДС ми діагностували у 39 (67,2\%) хворих, зокрема, дисфагію - у 32, дивертикуліт - у 10, хронічний бронхіт - у 21, анемію - у 2, кахексію - у 1 . Також безсимптомний перебіг ДС, особливо великих розмірів, не є свідченням відсутності аспіраційних бронхо-легеневих уражень [6]. Враховуючи наведене, активна хірургічна тактика у разі виявлення ДС великих розмірів цілком обгрунтована.

Кровопостачання нижніх відділів стравоходу вважають недостатнім [10], воно характеризується сегментарністю, пошаровістю. В літературі навіть є повідомлення про смерть пацієнта, спричинену гострим некрозом слизової оболонки нижньої третини стравоходу за наявності інтактних верхніх відділів внаслідок судинних уражень імовірно після лікування блокаторами протонної помпи [11]. Тому використання електрозварювальних технологій у режимі «перекриття» на етапах операції з максимально щадним виділенням ДС великих розмірів, фенестрації фіброзних залишкових порожнин слід вважати доцільним. Електротермічна денатурація білкових молекул, яка лежить в основі зварювання тканин, не спричиняє некрозу, зменшує зону запалення, потовщення та деформацію органів [12]. Додають впевненості у виборі активної хірургічної тактики дослідження [13], які характеризують багатошаровий плоский епітелій стравоходу як клітинну популяцію, що швидко відновлюється, а м'язові волокна стравоходу такими, що мають високий рівень відновлення після їх пошкодження. Клінічні дослідження підтверджують можливість закриття пошкоджень стравоходу консервативними методами лікування навіть за наявності такої загрозливої для життя патології, як спонтанний розрив стравоходу (синдром Бурхаве, 1724) [14].

ДС великих розмірів мають, як правило, широкі устя неправильної форми, розташовуються переважно на задньо-боковій стінці органа, ускладнюються дивертикулітом; у зв'язку з чим окремі автори використовують додатковий ручний шов слизової оболонки [6], апаратне прошивання устя дивертикула в поперечному напрямку [1] Під час виконання операцій з приводу ДС розмірами більше 6 см, які займають дві третини окружності стінки, з накладанням механічного шва запобігти звуженню просвіту, неспроможності допоможе клиноподібний шов 3 підкріпленням кута ручним швом та субопераційною перевіркою на герметичність.

\section{Висновки}

1. Хірургічне лікування ДС великих розмірів є обгрунтованим, сучасні методи діагностики потрібні як на доопераційному етапі, так і субопераційно.

2. За наявності фіброзно зміненої залишкової порожнини після видалення ДС доцільно виконати додаткову фенестрацію порожнини з застосуванням електрозварювальних технологій та окремим дренуванням для зменшення ризику виникнення гнійно-септичних ускладнень.

3. Ушивання основи ДС великих розмірів, які займають дві третини окружності стінки, клиноподібно в поперечному напрямку двома ендостеплерами дає змогу зберегти прохідність стравоходу. 


\section{Підтвердження \\ Фінансування}

Фінансування за власний рахунок

\section{Внесок авторів}

Всі автори внесли однаковий внесок у цю роботу.

Всі автори прочитали та схвалили остаточний варіант рукопису.

\section{Конфлікт інтересів}

Автори декларують відсутність конфлікту інтересів щодо цього рукопису.

\section{Згода на публікацію}

Всі автори дали згоду на публікацію цього рукопису.

\section{References}

1. Musabaev NC,Kalbarov FT, Abdiev CT. Sovremennye metody lecheniya divertikula pishevoda. Vestnik Kasanskoho meduniversiteta. 2017;(1):20-6. [In Russian].

2. Benacci JC, Deschamps C, Trastek VF, Allen MS, Daly RC, Pairolero PC. Epiphrenic diverticulum: Results of surgical treatment1993 May;55(5):1109-13; discussion 1114. PMID: 8494418.

3. Stanovenko VV, Charkevich NG, Vasiliev OM ,Scharov LI. Lecheniye divertikulov pishevoda. Vestnik Smolenskoy medakademii. 2010;(1):8892. [In Russian].

4. Cho M, Snyder C, Rivard D, Lim J. Multiple giant mid-thoracic esophageal diverticula in a teenager. Journal of Pediatric Surgery Case Reports. 2017 Dec;27:28-31. Available from https://www.sciencedirect.com/science/article/pii/S2213576617301628. doi: 10.1016/j.epsc.2017.08.019.

5 Ogloblin AL, Korolov MP, Fedotov LE, Klimov AL, Donijarov SL. Resultaty lecheniya divertikula Zenkera khirurqicheskim i endoskopicheskim sposobom. In: Sovremennye problemy nauki i obrasovaniya. Sankt-Peterburg. 2018;(3):7-8. [In Russian].

6. Bagirov MM, Verechako RI, Agaev AN. Chirurgicheskoye lecheniye ehifrenalnoho divertikula pishevoda. Khirurhiia Ukrainy. 2014;(3):10 6. [In Russian].

7. Svane S. Giant midesophageal pulsion diverticulum: a report of two operated cases. Ann Thorac Surg. 2001 May;71(5):1692-4. doi:10.1016/ S0003-4975(00)02297-9.

8. Shalimov AA, Saynko VF, Shalimov SA. Khirurgiya pishevoda. 1975; -368. [In Russian].

9. Achkar E. Esophageal diverticula. Gastroenterol Hepatol (N Y). 2008 Oct;4(10):691-3. PMID: 21960888.

10. Ivanova VD. Izbrannye lekcyi po operativnoj khirurgyi i klinicheskoy anatomyi. Izd. Samarskoho meduniversiteta. 2009;(1):110-2. [In Russian].

11. Sachek MG, Ruseckaya MD, Emaschkevich SI, Kondratyev NM, Jankovskiy AI, Podolinskiy YS. Ostryi nekroz pishevoda. Novosti khirurgyi. 2017;25(1):93-8. [In Russian].

12. Babiy AM, Schevchenko BF, Ratcyk VM, Kunkin DA. Opyt primenenia elektrosvarochnykh tekhnologiy v khirurgyceskom lechenyi bolnykh s abdominalnoy patologiey. Gastroenterologia . 2014;(2):61-8. [In Russian].

13. Danilov RK, Afanasjev JI, Bazenov DV, Borovaja TG,Valcovich EI, Verin VK. Rukovodstvo po gystologyi. 2011;(2):103-10. [In Russian].

14. Usenko AYu, Lavrik AS, Movchan BB, Kondratenko BI, Manoilo NV, Rasdobudko YuM. Spontannyj rasryv pishevoda. Kharkivska khirurhychna schkola. 2014;(3):105-8. [In Russian]

Отримана 26.09.2018 